Amsterdam Expeditions to the West Indian Islands, Report 50*

\title{
NAIDIDAE (OLIGOCHAETA) FROM SUBTERRANEAN WATERS OF WEST INDIAN ISLANDS - DISTRIBUTION, TAXONOMIC REMARKS AND DESCRIPTION OF A NEW SPECIES
}

\author{
by \\ ELŻBIETA DUMNICKA \\ Institute of Freshwater Biology, Polish Academy of Sciences, ul. Sławkowska 17, 31-016 Kraków, Poland
}

\begin{abstract}
Fourteen species of the family Naididae from various subterranean habitats are recorded. Taxonomic remarks concerning variations in setation are provided. The structure of the genital organs of some species is described. A new species of the genus Dero is described.

\section{RÉSUMÉ}

Quatorze espèces de la famille des Naididae ont été signalées dans des milieux souterrains. On présente des observations taxonomiques concernant des variations de la sétation. Pour quelques espèces on décrit la structure des organes génitaux. Une espèce nouvelle du genre Dero est décrite.
\end{abstract}

\section{INTRODUCTION}

This is the second part of a series of papers treating the oligochaetes collected by the Amsterdam Expeditions to the West Indian Islands (leader Prof. Dr. Jan H. Stock). The first part dealt with the Tubificidae (Dumnicka, 1983).

The family Naididae is very common in the material investigated, present in $47 \%$ of the samples. The number of species is also considerably higher than that of other families of oligochaetes: of 21 species identified so far, 14 belong to this family (Dumnicka, 1986).

* Report 49 has been published in Bijdragen tot de Dierkunde, 56 (1): 165-180 (1986). The fieldwork during which the material, described in the present paper, was collected, has been financially supported by the Netherlands Foundation for the Advancement of Tropical Research (WOTRO), The Hague, the Treub Maatschappij, Utrecht, and the Beijerinck-Popping Fonds, Amsterdam.
Naididae are common in fresh waters all over the world. The genera Dero (Aulophorus) and Pristina in particular (which are most frequent in the material investigated) comprise cosmopolitan species (Timm, 1980). These genera happen to be characteristic of the water bodies in South America as well (Du BoisReymond Marcus, 1947, 1949; Howmiller, 1974; Di Persia, 1980).

Reproduction in the Naididae is usually asexual, which facilitates their wide distribution and the development of diverse geographical forms. Even populations from different islands differ in size, and in the presence or absence of papillae on some segments. Small differences are also noted in the setation. Moreover, specimens from subterranean waters are smaller than usual. In some cases, these variations make correct identification difficult.

The specimens are preserved in the collections of the Zoölogisch Museum, Amsterdam (ZMA) and the Polish Academy of Sciences, Kraków (PAS).

\section{TAXONOMY}

\section{Slavina evelinae (Marcus, 1942)}

(Fig. 1)

Material. - Amsterdam Expeditions to the West Indian Islands, sta. 78/46. Antigua: Parish of St. John $\left(17^{\circ} 07^{\prime} 07^{\prime \prime} \mathrm{N} 61^{\circ} 53^{\prime} 22^{\prime \prime} \mathrm{W}\right)$; well, square opening, diam. $1.3 \mathrm{~m}$, garbage, palm leaves; 13 April 1978. Fourteen specimens (ZMA).

Body wall with rows of sensory papillae (fig. 1a) covered by a sheath composed of small inorganic particles. Hair setae from segment VI, 


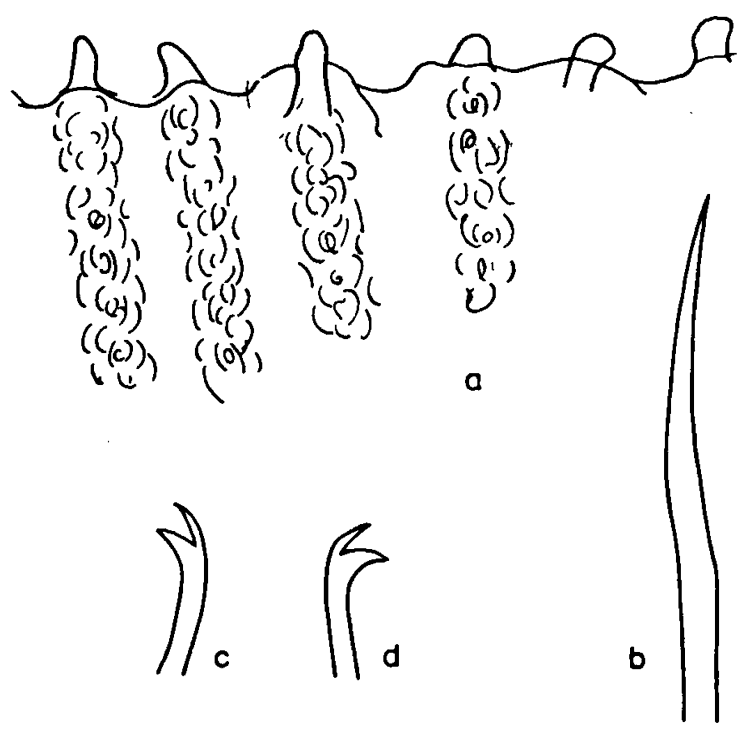

Fig. 1. Slavina evelinae (Marcus, 1942): a, body wall with rows of papillae; $b$, needle seta; $c$, anterior ventral seta; $d$, posterior ventral seta.

usually single, 255-315 $\mu \mathrm{m}$ long. Needle setae simple-pointed (fig. 1b) with distal part slightly curved, 85-105 $\mu \mathrm{m}$ long. Anterior ventral setae 3-5 per bundle, 90-102 $\mu \mathrm{m}$ long with distal teeth slightly longer (fig. 1c). From segment VI distal teeth become shorter and thinner than proximal ones (fig. 1d). Length of posterior ventral setae 98 to $112 \mu \mathrm{m}$.

According to Marcus (1942) longer posterior ventral setae are observed only in immature specimens.

Distribution: This species was described from Brazil (Marcus, 1942) and it was up to now recorded only from South America (Di Persia, 1980).

\section{Dero (Dero) digitata (Müller, 1773)}

Material. - Amsterdam Expeditions to the West Indian Islands, sta. 78/239. Haiti: Dépt. du Nord, Limbé, S. side road D $100\left(19^{\circ} 42^{\prime} 05^{\prime \prime} \mathrm{N} 72^{\circ} 23^{\prime} 53^{\prime \prime} \mathrm{W}\right)$; open well, round, diam. $1.5 \mathrm{~m}$; chlorinity $100 \mathrm{mg} / 1$; 10 May 1978. Four immature specimens (ZMA).

From segment VI dorsal setae with single hair and needle setae. Hairs 180-200 $\mu \mathrm{m}$ long, needles 60-74 $\mu \mathrm{m}$ long, with distal teeth slightly longer than the proximal ones. Anterior ventral setae 3-4 per bundle, with distal teeth distinctly longer. From segment VI teeth of the same length but the proximal ones thicker. Length of anterior ventral setae 97-123 $\mu \mathrm{m}$, posterior setae shorter $(66-84 \mu \mathrm{m})$. Four pairs of gills present.

Distribution: Cosmopolitan species, known from many places in South America (Di Persia, 1980).

\section{Dero (Dero) obtusa d'Udekem, 1855} (Fig. 2)

Material. - Amsterdam Expeditions to the West Indian Islands, sta. 78/105. Anegada: The Settlement, Bobo Well (18 $\left.43^{\prime} 19^{\prime \prime} \mathrm{N} 64^{\circ} 18^{\prime} 59^{\prime \prime} \mathrm{W}\right)$; clean; chlorinity 440 $\mathrm{mg} / \mathrm{l} ; 22$ April 1978. Nine specimens (ZMA).

Sta. 78/107. Anegada: The Settlement, Smith's Well $\left(18^{\circ} 43^{\prime} 16^{\prime \prime} \mathrm{N} 69^{\circ} 19^{\prime} 03^{\prime \prime} \mathrm{W}\right)$; chlorinity $1160 \mathrm{mg} / \mathrm{l} ; 22$ April 1978. Five specimens (ZMA).

Sta. 78/240. Haiti: Dépt. du Nord, Limbé, S. side road D $100\left(19^{\circ} 42^{\prime} 05^{\prime \prime} \mathrm{N} 72^{\circ} 23^{\prime} 53^{\prime \prime} \mathrm{W}\right)$; round well, closed; chlorinity $240 \mathrm{mg} / \mathrm{l} ; 10 \mathrm{May} 1978$. Two specimens (PAS).

Sta. 78/322. Venezuela: Dto. Falcón, N. of road Buena Vista-Maicara (c. $11^{\circ} 52^{\prime} 28^{\prime \prime} \mathrm{N}$, c. $69^{\circ} 55^{\prime} 40^{\prime \prime} \mathrm{W}$ ); square well, covered, windpump; chlorinity $620 \mathrm{mg} / \mathrm{l} ; 26$ May 1978. One specimen (PAS).

Hair setae $210-215 \mu \mathrm{m}$ long, 1 per bundle, needle setae 60-64 $\mu \mathrm{m}$ long, with short, equal teeth (fig. 2a). Length of anterior ventral setae 105$120 \mu \mathrm{m}$, teeth long, the distal ones longer than the proximal ones (fig. 2b). From segment VI ventral setae 67-78 $\mu \mathrm{m}$ long, distal teeth slightly shorter (fig. 2c). Towards end of body distal teeth become shorter. Three pairs of gills present, their shape depends on the degree of shrinkage following fixation (fig. 2d).

Distribution: Dero obtusa is known from many places in South America (Marcus, 1943; Harman, 1974; Di Persia, 1980).

\section{Dero (Dero) sawayai Marcus, 1943}

(Fig. 3)

Material. - Amsterdam Expeditions to the West Indian Islands, sta. 78/101. Anegada: S. of Loblolly Bay (c. $18^{\circ} 44^{\prime} 08^{\prime \prime} \mathrm{N}$, c. $\left.64^{\circ} 18^{\prime} 43^{\prime \prime} \mathrm{W}\right)$; shallow, natural karst waterhole with fallen leaves; chlorinity $1000 \mathrm{mg} / \mathrm{l} ; 22$ April 1978. Two specimens (ZMA).

Sta. 78/103. Anegada: Tom Berry Well $\left(18^{\circ} 43^{\prime} 38^{\prime \prime} \mathrm{N}\right.$ $\left.64^{\circ} 18^{\prime} 57^{\prime \prime} \mathrm{W}\right)$; chlorinity $560 \mathrm{mg} / \mathrm{l}$; 22 April 1978. Sixtythree specimens (PAS). 

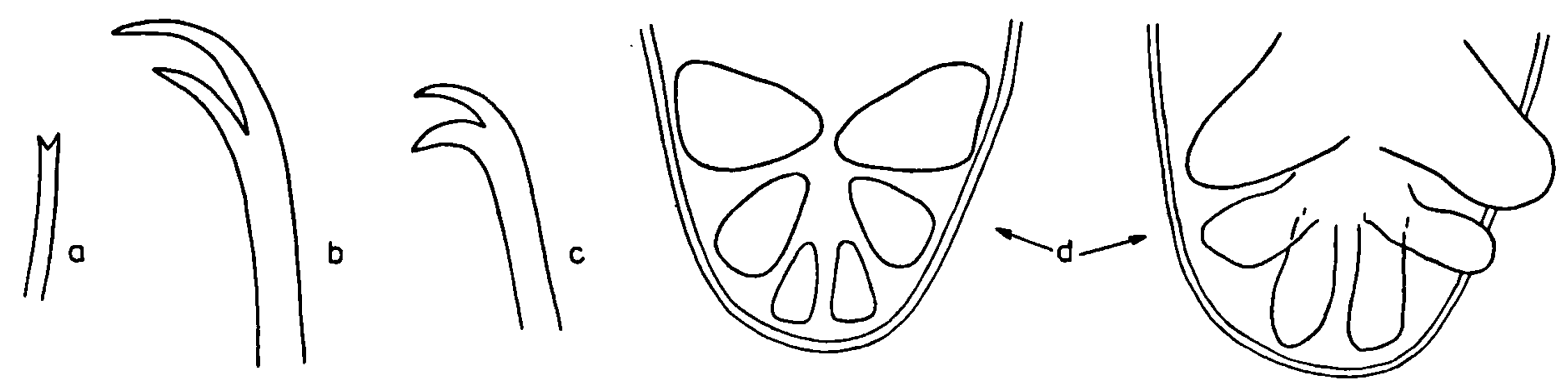

Fig. 2. Dero obtusa d'Udekem, 1855: a, needie seta; b, anterior ventral seta; c, posterior ventral seta; d, branchial apparatus retracted and open.

Sta. 78/109. Anegada: The Settlement, Winston's Well $\left(18^{\circ} 43^{\prime} 14^{\prime \prime} \mathrm{N} 64^{\circ} 19^{\prime} 02^{\prime \prime} \mathrm{W}\right)$; chlorinity $1320 \mathrm{mg} / \mathrm{l} ; 22$ April 1978. One specimen (ZMA).

Sta. 78/122. Virgin Gorda: The Spring (South Sound) in Black Rock Ghut $\left(18^{\circ} 29^{\prime} 05^{\prime \prime} \mathrm{N} 64^{\circ} 23^{\prime} 33^{\prime \prime} \mathrm{W}\right)$; open spring, slowly running into basin, leaves, cows, shadowed, volcanic outcrops; chlorinity $1760 \mathrm{mg} / \mathrm{l} ; 24$ April 1978. Four specimens (ZMA).

Sta. 78/132. Tortola: Road Town, Port Purcell Warehouse, S. of road $\left(18^{\circ} 25^{\prime} 55^{\prime \prime} \mathrm{N} 64^{\circ} 36^{\prime} 42^{\prime \prime} \mathrm{W}\right)$; clean well; chlorinity $480 \mathrm{mg} / 1$; 25 April 1978. Nine specimens (PAS).

Sta. 78/164. St. Thomas: S. slope Wintberg Peak, E. of Raphune $\left(18^{\circ} 20^{\prime} 16^{\prime \prime} \mathrm{N} 64^{\circ} 54^{\prime} 20^{\prime \prime} \mathrm{W}\right)$; large well, diam. c. $6 \mathrm{~m}$, under roof; chlorinity $130 \mathrm{mg} / \mathrm{l} ; 28$ April 1978 . One specimen (ZMA).

Sta. 78/239. Haiti: Dépt. du Nord, Limbé, S. side road D $100\left(19^{\circ} 42^{\prime} 05^{\prime \prime} \mathrm{N} 72^{\circ} 23^{\prime} 53^{\prime \prime} \mathrm{W}\right)$; open well, round, diam. $1.5 \mathrm{~m}$; chlorinity $100 \mathrm{mg} / \mathrm{l} ; 10 \mathrm{May} 1978$. One mature specimen (ZMA).

Sta. 78/326. Venezuela: Dto. Falcón, c. $17 \mathrm{~km} \mathrm{~N}$. of Los Taques (c. $11^{\circ} 56^{\prime} 30^{\prime \prime} \mathrm{N}$, c. $70^{\circ} 12^{\prime} 40^{\prime \prime} \mathrm{W}$ ); covered well, diam. $2.5 \mathrm{~m}$, troughs, windpump; chlorinity 1560 $\mathrm{mg} / \mathrm{l} ; 26$ May 1978. Two specimens (ZMA).

A small species. Dorsal setae begin from segment VI, hairs smooth, 94-103 $\mu \mathrm{m}$ long,

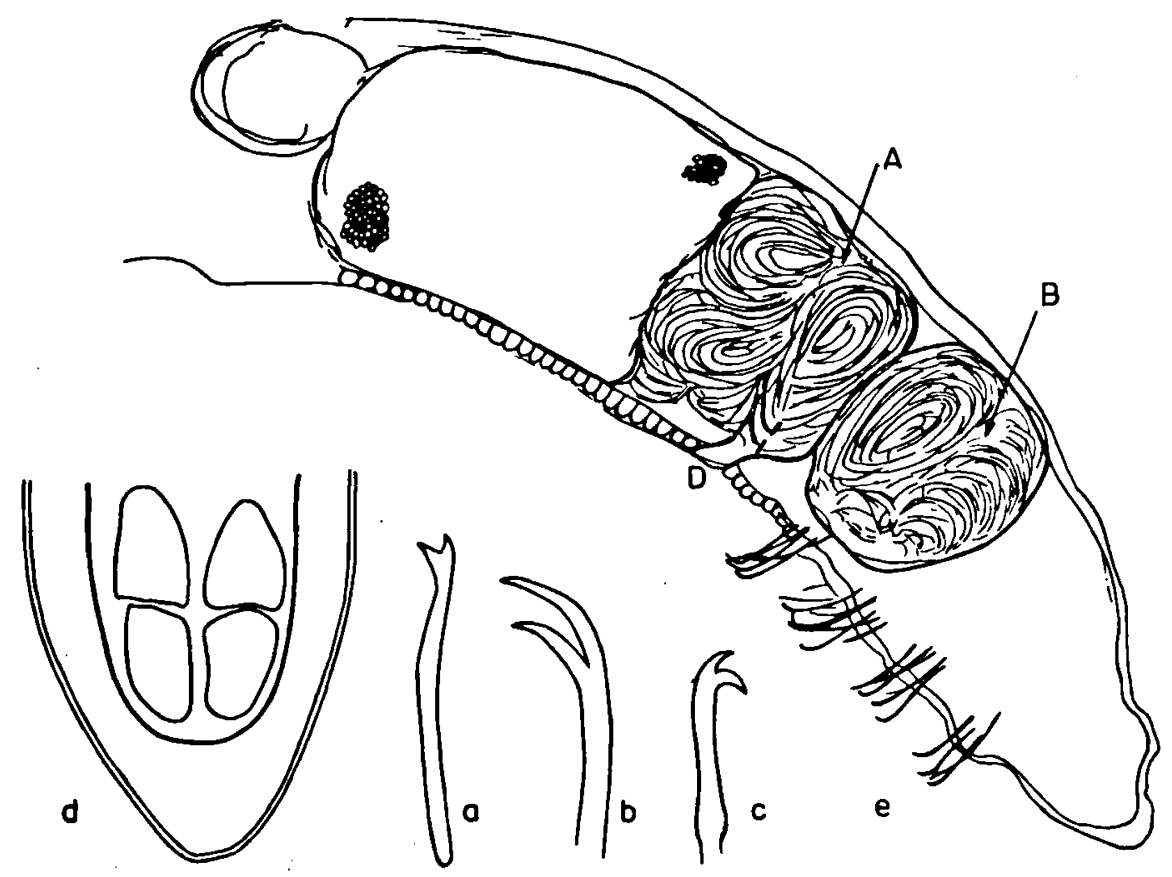

Fig. 3. Dero sawayai Marcus, 1943: a, needle seta; b, anterior ventral seta; c, posterior ventral seta; d, branchial apparatus; e, anterior end of the specimen with developed genital organs $(A=$ atrium, $B=$ spermatheca, $D=$ ectal duct of atrium). 
needles bifid with distal teeth shorter than proximal ones (fig. 3a), 32-39 $\mu \mathrm{m}$ long. Three to four setae in ventral anterior bundles, $67-78 \mu \mathrm{m}$ long, with distal teeth distinctly longer (fig. $3 b$ ). Posterior setae 40-48 $\mu \mathrm{m}$ long, with distal teeth thinner and shorter than the proximal ones (fig. 3c). This difference becomes more apparent posteriorly. Branchial fossa with only two pairs of gills (fig. 3d).

Genital organs not yet described. On the basis of one available mature specimen from sta. 78/239 the structure of the genital organs could not be examined sufficiently. Spermatheca globular, ectal duct invisible (fig. 3e). Atrium almost spherical, ectal duct short. Penial setae absent.

Distribution: Known from South America (Brinkhurst \& Jamieson, 1971) and India (Naidu, 1962).

Dero (Dero) haitiensis sp. $n$.

(Fig. 4)

Material. - Amsterdam Expeditions to the West Indian Islands, sta. 78/238. Haiti: Dépt. du Nord, Limbé, N. side road D $100\left(19^{\circ} 42^{\prime} 29^{\prime \prime} \mathrm{N} 72^{\circ} 23^{\prime} 53^{\prime \prime} \mathrm{W}\right)$; closed well, round, diam. $1 \mathrm{~m}$, filamentous algae; chlorinity 240 $\mathrm{mg} / \mathrm{l} ; 10$ May 1978. Holotype and 1 mature paratype and 10 immatures (ZMA).

Dorsal setae begin from segment VI. Hair setae short (67-82 $\mu \mathrm{m})$ and smooth. Needle setae pectinate with short diverging lateral teeth (fig. 4a) and usually only 2 intermediate teeth. Needles 28-35 $\mu \mathrm{m}$ long. Per bundle 1 hair and 1 needle. Ventral setae of segments II to $\mathrm{V}$ thin and long (85-98 $\mu \mathrm{m})$, with distal teeth longer than proximal teeth (figs. 4b, c). From segment VI setae short $(45-49 \mu \mathrm{m})$ with distal teeth thin and half as long as proximal ones (figs. $4 \mathrm{~d}$, e). Three to four setae in each ventral bundle. Penial setae unmodified. Stomach dilatation sudden in the beginning of segment VIII. Only two pairs of gills. In the available material, preserved in formalin, they are small and bulbous (fig. 4f).

Genital organs in segments V-VII. Spermatheca with globular ampulla and short, narrow ectal duct. Prostate glands present, but the junction with the atrium invisible. Vas deferens long, coiled, entering the atrium almost apically; atrial ampulla long, clavate, ectal duct of the same length as ampulla. Ectal orifice of the duct surrounded by glands (fig. $4 \mathrm{~g}$ ).

Discussion: Dero haitiensis sp. n. differs from all other species of this genus (except Dero asiatica Cernosvitov, 1930) in having pectinate needle setae. Some differences in the structure of the genital organs enable differentiating Dero haitiensis sp. n. from Dero asiatica (table I). Also the setal apparatus of these two species differs in some details. The teeth of ventral setae in segment VI are almost equal in $D$. asiatica, whereas in $D$. haitiensis sp. n. distal teeth are distinctly shorter. Needles of $D$. asiatica are similar to those of Tubifex tubifex (Müller, 1774) (cf. Cernosvitov, 1930), while in $D$. haitiensis sp. $\mathrm{n}$. they are thin and have thin and short teeth.

Dero asiatica appears to be endemic to Turkestan, where it is common in various water bodies (Semernoy \& Belozub, 1979).

\section{TABLE I}

Comparison of the structure of the genital organs in Dero (Dero) asiatica Černosvitov, 1930 and D. (D.) haitiensis sp. $n$.

\begin{tabular}{|c|c|c|}
\hline Organ & Dero asiatica & Dero haitiensis \\
\hline $\begin{array}{l}\text { Spermathecal } \\
\text { ampulla }\end{array}$ & $\begin{array}{l}\text { small, thin- } \\
\text { walled }\end{array}$ & $\begin{array}{l}\text { globular, thick } \\
\text { wall }\end{array}$ \\
\hline $\begin{array}{l}\text { Spermathecal } \\
\text { duct }\end{array}$ & short & short \\
\hline Vas deferens & short, wide & long, coiled \\
\hline Atrial ampulla & small, globular & large, clavate ${ }^{*}$ \\
\hline Atrial duct & short, narrow & $\begin{array}{c}\text { almost same } \\
\text { length as } \\
\text { ampulla }\end{array}$ \\
\hline \multirow[t]{2}{*}{$\begin{array}{l}\text { Gland cells } \\
\text { around ectal } \\
\text { orifice of } \\
\text { ampulla }\end{array}$} & & \\
\hline & present & present \\
\hline
\end{tabular}

* The wall may become thin when the ampulla is filled with spermatophores, but in this case the ampulla is obviously dilated.

Dero (Aulophorus) superterrena Michaelsen, 1912

(Fig. 5)

Material. - Amsterdam Expeditions to the West Indian Islands, sta. 74/18. Saba: Booby Hill, halfway Wind- 

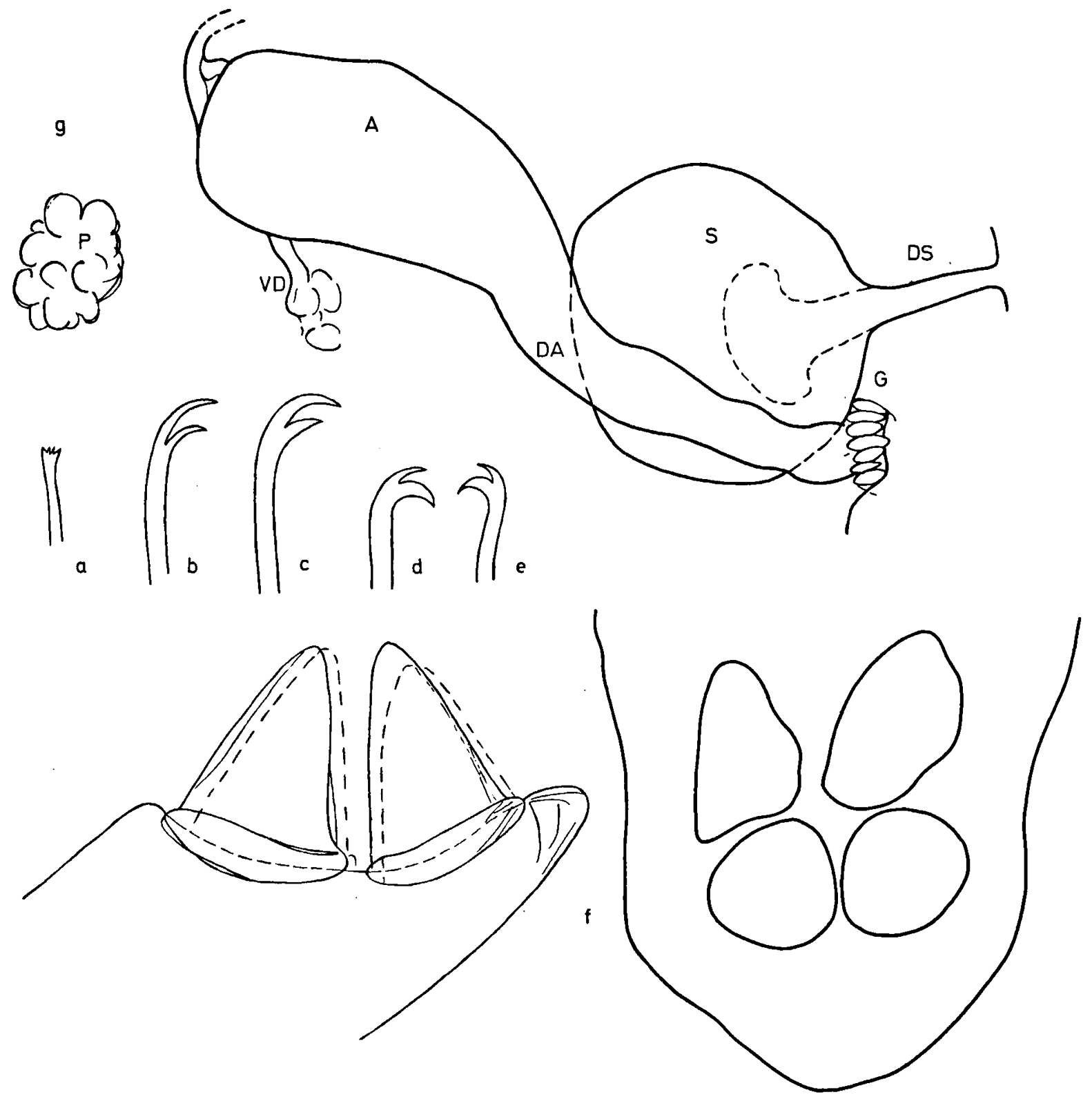

Fig. 4. Dero haitiensis sp. n.: a, needle seta; b, ventral seta of segment II; c, ventral seta of segment III; d, ventral seta of segment VI; e, ventral seta of terminal segments; $f$, branchial apparatus; $g$, genital organs ( $A=$ atrial ampulla, $\mathrm{DA}=$ ectal duct of atrium, $\mathrm{G}=$ glands at orifice of ectal duct of atrium, $\mathrm{VD}=$ vas deferens, $\mathrm{P}=$ prostate glands, $\mathrm{S}=\mathrm{sper}-$ matheca, DS = ectal duct of spermatheca).

wardside $\left(17^{\circ} 37^{\prime} 31^{\prime \prime} \mathrm{N} \quad 63^{\circ} 13^{\prime} 49^{\prime \prime} \mathrm{W}\right)$; cistern, near ruined house, depth $40 \mathrm{~cm}$, leaves; 3 February 1974 . One hundred and thirty-five specimens (ZMA).

Dorsal setae begin in segment IV. Bundles with 2 hairs 270-337 $\mu \mathrm{m}$ long and 2 needles 52-72 $\mu \mathrm{m}$ long, with distal end slightly bent and equal, and short but stout teeth (fig. 5a). Ventral setae of anterior segments a little longer $(80-92 \mu \mathrm{m})$ than those of posterior ones (74-85 $\mu \mathrm{m})$. In anterior segments 6-8 setae per bundle, with distal teeth slightly longer (fig. 5b); in posterior segments 4-5 setae per bundle, with distal 

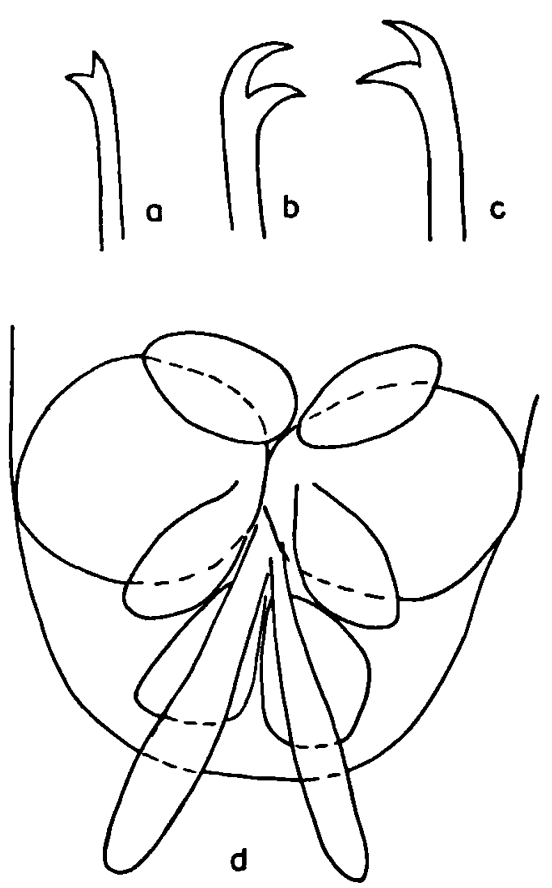

Fig. 5. Dero (Aulophorus) superterrena Michaelsen, 1912: a, needle seta; $b$, anterior ventral seta; $c$, posterior ventral seta; d, branchial apparatus.

teeth slightly shorter than proximal ones (fig. 5c). Stomach dilatation in front of segment $X$. Branchial apparatus consisting of 1 pair of finger-shaped palps and 4 pairs of gills: 1 large and 3 small ones (fig. $5 \mathrm{~d}$ ).

Distribution: So far Aulophorus superterrenus was known only from the leaf-water of epiphytes and terrestrial bromeliads (Di Persia, 1980) and from holes in trees in Malaysia (Stephenson, 1931). The occurrence of this species in a cistern shows that it can also live in an artificial "superterraneous" environment.

\section{Dero (Aulophorus) furcata (Müller, 1773)}

Material. - Amsterdam Expeditions to the West Indian Islands, sta. 74/9. St. Martin, French side: Slope of Mont Vernon, left side road Orléans - Grand' Case $\left(18^{\circ} 05^{\prime} 07^{\prime \prime} \mathrm{N} 63^{\circ} 01^{\prime} 46^{\prime \prime} \mathrm{W}\right)$; well, fuel pump, in dry bed of rain gully; chlorinity $780 \mathrm{mg} / \mathrm{l} ; 1$ February 1974 . One specimen (ZMA).

Sta. 74/23. Curaçao: Hato plain, Cueba di Raton (c. $12^{\circ} 12^{\prime} 22^{\prime \prime} \mathrm{N}$, c. $68^{\circ} 59^{\prime} 31^{\prime \prime} \mathrm{W}$ ); drip water in cave, near entrance; chlorinity $891 \mathrm{mg} /$; 20 January 1974. One specimen (ZMA).
Sta. 78/20. Barbuda: village of Codrington $\left(17^{\circ} 38^{\prime} 20^{\prime \prime} \mathrm{N} 61^{\circ} 49^{\prime} 32^{\prime \prime} \mathrm{W}\right)$; round well, 2 openings, slightly polluted; chlorinity $1040 \mathrm{mg} / 1 ; 9$ April 1978. Four specimens (ZMA).

Sta. 78/64. St. Martin, French Side: E. side of road N7 $\left(18^{\circ} 03^{\prime} 29^{\prime \prime} \mathrm{N} 63^{\circ} 05^{\prime} 16^{\prime \prime} \mathrm{W}\right)$; round well, diam. c. $4 \mathrm{~m}$, small opening, troughs, clean; chlorinity $840 \mathrm{mg} / \mathrm{l} ; 17$ April 1978. One specimen (ZMA).

Sta. $78 / 83$. Anguilla: Station Valley Well $\left(18^{\circ} 12^{\prime} 31^{\prime \prime N}\right.$ $\left.63^{\circ} 03^{\prime} 49^{\prime \prime} \mathrm{W}\right)$; round, large, open, diam. c. $3.5 \mathrm{~m}$, taste fresh; 19 April 1978. Eight specimens (ZMA).

Sta. 78/84. Anguilla: Quarter Well $\left(18^{\circ} 13^{\prime} 12^{\prime \prime} \mathrm{N}\right.$ $63^{\circ} 02^{\prime} 36^{\prime \prime} \mathrm{W}$ ); round, carved, diam. c. $1.5 \mathrm{~m}$, open; chlorinity $800 \mathrm{mg} / \mathrm{l} ; 19$ April 1978. Thirteen specimens (ZMA).

Sta. 78/103. Anegada: Tom Berry Well $\left(18^{\circ} 43^{\prime} 38^{\prime \prime} \mathrm{N}\right.$ $\left.64^{\circ} 18^{\prime} 57^{\prime \prime} \mathrm{W}\right)$; chlorinity $560 \mathrm{mg} / \mathrm{l}$; 22 April 1978. One specimen (PAS).

Sta. 78/114. Virgin Gorda: Little Dix Well (S. slope Dovers Hill) $\left(18^{\circ} 27^{\prime} 19^{\prime \prime} \mathrm{N} \quad 64^{\circ} 26^{\prime} 02^{\prime \prime} \mathrm{W}\right)$; clean; chlorinity $1440 \mathrm{mg} / \mathrm{l} ; 24$ April 1978. One specimen (ZMA).

Sta. 78/118. Virgin Gorda: meadow E. of Spanish Town (18 $\left.26^{\prime} 30^{\prime \prime} \mathrm{N} 64^{\circ} 26^{\prime} 19^{\prime \prime} \mathrm{W}\right)$; well; chlorinity 960 mg/l; 24 April 1978. Three specimens (ZMA).

Sta. 78/120. Virgin Gorda: Spanish Town, Crossroad Well $\left(18^{\circ} 26^{\prime} 42^{\prime \prime} \mathrm{N} 64^{\circ} 26^{\prime} 23^{\prime \prime} \mathrm{W}\right)$; closed, used by tank cars; chlorinity $440 \mathrm{mg} / \mathrm{l} ; 24$ April 1978. Five specimens (ZMA).

Sta. 78/121. Virgin Gorda: Handsome Bay, in meadow $\left(18^{\circ} 27^{\prime} 37^{\prime \prime} \mathrm{N} 64^{\circ} 25^{\prime} 34^{\prime \prime} \mathrm{W}\right)$; partly closed well; chlorinity $1680 \mathrm{mg} / 1$; 24 April 1978. One specimen (ZMA).

Sta. 78/126. Virgin Gorda: Blackbeards Tavern $\left(18^{\circ} 26^{\prime} 30^{\prime \prime} \mathrm{N} 64^{\circ} 26^{\prime} 19^{\prime \prime} \mathrm{W}\right)$; deep borehole, closed, with electr. pump; chlorinity $1160 \mathrm{mg} / \mathrm{l} ; 25$ April 1978. Two specimens (ZMA).

Sta. 78/127. Virgin Gorda: Princess' Quarters, in a house $\left(18^{\circ} 26^{\prime} 43^{\prime \prime} \mathrm{N} 64^{\circ} 26^{\prime} 09^{\prime \prime} \mathrm{W}\right)$; deep borehole, closed, with electr. pump; chlorinity $1040 \mathrm{mg} / \mathrm{l} ; 25$ April 1978. Twenty-eight specimens (ZMA).

Sta. 78/131. Tortola: Road Town, Port Purcell Warehouse (S. of road) $\left(18^{\circ} 25^{\prime} 52^{\prime \prime} \mathrm{N} 64^{\circ} 36^{\prime} 41^{\prime \prime} \mathrm{W}\right)$; large well, mostly covered; chlorinity $360 \mathrm{mg} / \mathrm{l} ; 25$ April 1978. Thirty-eight specimens (ZMA).

Sta. 78/132. Tortola: c. $75 \mathrm{~m} \mathrm{N.W.} \mathrm{of} \mathrm{78/131}$ $\left(18^{\circ} 25^{\prime} 55^{\prime \prime} \mathrm{N} 64^{\circ} 36^{\prime} 42^{\prime \prime} \mathrm{W}\right)$; clean well; chlorinity 480 mg/1; 25 April 1978. Two specimens (PAS).

Sta. 78/138. Tortola: East End, The Fountain (S. side of road) $\left(18^{\circ} 26^{\prime} 27^{\prime \prime} \mathrm{N} 64^{\circ} 34^{\prime} 05^{\prime \prime} \mathrm{W}\right)$; large, open well, with troughs, muddy; chlorinity $840 \mathrm{mg} / 1 ; 25$ April 1978. Two specimens (ZMA).

Sta. 78/144. Tortola: Duffs Bottom Pond, N. side of road $\left(18^{\circ} 24^{\prime} 42^{\prime \prime} \mathrm{N} \quad 64^{\circ} 37^{\prime} 28^{\prime \prime} \mathrm{W}\right)$; well, troughs; chlorinity $720 \mathrm{mg} / \mathrm{l} ; 26$ April 1978. Two specimens (ZMA).

Sta. 78/145. Tortola: Albion Ghut, near school $\left(18^{\circ} 24^{\prime} 46^{\prime \prime} \mathrm{N} 64^{\circ} 37^{\prime} 53^{\prime \prime} \mathrm{W}\right)$; open well, clean; 26 April 1978. Five specimens (ZMA). 
Sta. 78/191. Culebra: Finca Feliciano (N. slope of Cerro Balcón) $\left(18^{\circ} 19^{\prime} 17^{\prime \prime} \mathrm{N} 65^{\circ} 15^{\prime} 40^{\prime \prime} \mathrm{W}\right)$; round well, closed, diam. $2 \mathrm{~m}$, in alluvial sands; chlorinity $1280 \mathrm{mg} / \mathrm{l}$; 2 May 1978. Two specimens (PAS).

Sta. 78/203. Haiti: Dépt. de l'Ouest, Gressier, N. side road D $200\left(18^{\circ} 32^{\prime} 23^{\prime \prime} \mathrm{N} 72^{\circ} 31^{\prime} 13^{\prime \prime} \mathrm{W}\right)$; round well, closed, diam. $1 \mathrm{~m}$; chlorinity $40 \mathrm{mg} / \mathrm{l}$; 5 May 1978. One specimen (ZMA).

Sta. 78/212. Haiti: Dépt. du Sud-Est, Cayes-Jacmel, $\mathrm{N}$. side of road, backyard of house $\left(18^{\circ} 13^{\prime} 54^{\prime \prime} \mathrm{N}\right.$ $72^{\circ} 23^{\prime} 49^{\prime \prime} \mathrm{W}$ ); round well, closed, diam. $1 \mathrm{~m}$; chlorinity $40 \mathrm{mg} / \mathrm{l} ; 5 \mathrm{May}$ 1978. Twenty-nine specimens (ZMA).

Sta. 78/213. Haiti: Dépt. du Sud-Est, Cayes-Jacmel, near $78 / 212$, near house, $N$. of road $\left(18^{\circ} 13^{\prime} 54^{\prime \prime} \mathrm{N}\right.$ $72^{\circ} 23^{\prime} 50^{\prime \prime} \mathrm{W}$ ); round well, open, diam. $0.75 \mathrm{~m}$, clean; chlorinity $40 \mathrm{mg} / 1$; 5 May 1978. Seven specimens (PAS).

Sta. 78/214. Haiti: Dépt. du Sud-Est, Just W. of Marigot, S. side of road, backyard of house, close to the sea $\left(18^{\circ} 14^{\prime} 07^{\prime \prime} \mathrm{N} 72^{\circ} 20^{\prime} 24^{\prime \prime} \mathrm{W}\right)$; open well, diam. $0.75 \mathrm{~m}$; chlorinity $240 \mathrm{mg} / \mathrm{l} ; 5$ May 1978. Three specimens (ZMA).

Sta. 78/215. Haiti: Dépt. du Sud-Est, Hamlet Raymond, Puits Conseil Communautaire (W. of CayesJacmel) $\left(18^{\circ} 13^{\prime} 30^{\prime \prime} \mathrm{N} 72^{\circ} 25^{\prime} 36^{\prime \prime} \mathrm{W}\right)$; round well, closed, diam. $0.75 \mathrm{~m}$, fairly clean; chlorinity $30 \mathrm{mg} / \mathrm{l} ; 5$ May 1978. One specimen (ZMA).

Sta. 78/216. Haiti: Dépt. du Sud-Est, Jacmel, house Dr. Abel Gousse, near Riv. des Orangiers $\left(18^{\circ} 14^{\prime} 31^{\prime \prime} \mathrm{N}\right.$ $\left.72^{\circ} 32^{\prime} 04^{\prime \prime} \mathrm{W}\right)$; neglected well, covered; chlorinity 50 $\mathrm{mg} / \mathrm{l} ; 5$ May 1978. Three specimens (ZMA).

Sta. 78/238. Haiti: Dépt. du Nord, Limbé, N. side road D $100\left(19^{\circ} 42^{\prime} 29^{\prime \prime} \mathrm{N} \quad 72^{\circ} 23^{\prime} 53^{\prime \prime} \mathrm{W}\right) ;$ closed well, round,diam. $1 \mathrm{~m}$, filamentous algae; chlorinity $240 \mathrm{mg} / \mathrm{l}$; 10 May 1978. Seven specimens (ZMA).

Sta. 78/239. Haiti: Dépt. du Nord, Limbé, S. side road D 100 , near sta. $78 / 238\left(19^{\circ} 42^{\prime} 05^{\prime \prime} \mathrm{N} 72^{\circ} 23^{\prime} 53^{\prime \prime} \mathrm{W}\right)$; open well, round, diam. $1.5 \mathrm{~m}$; chlorinity $100 \mathrm{mg} / \mathrm{l} ; 10 \mathrm{May}$ 1978. Three specimens (ZMA).

Sta. 78/240. Haiti: Dépt. du Nord, near sta. 78/239 $\left(19^{\circ} 42^{\prime} 05^{\prime \prime} \mathrm{N} 72^{\circ} 23^{\prime} 53^{\prime \prime} \mathrm{W}\right)$; closed well, round, diam. 1 $\mathrm{m}$; chlorinity $240 \mathrm{mg} / \mathrm{l} ; 10$ May 1978. One specimen (PAS).
Sta. 78/241. Haiti: Dépt. du Nord, village of CampCoq (S. of Limbé), well of school (E. side of road D 100) $\left(19^{\circ} 40^{\prime} 03^{\prime \prime} \mathrm{N} 72^{\circ} 25^{\prime} 06^{\prime \prime} \mathrm{W}\right)$; square, closed, windpump broken; chlorinity $200 \mathrm{mg} / \mathrm{l} ; 10$ May 1978. Sixty-six specimens (PAS).

Sta. 78/320. Venezuela: Dto. Falcón, well (c. $11^{\circ} 53^{\prime} 05^{\prime \prime} \mathrm{N}$, c. $\left.69^{\circ} 55^{\prime} 56^{\prime \prime} \mathrm{W}\right)$; chlorinity $790 \mathrm{mg} / \mathrm{l} ; 26$ May 1978. One specimen (ZMA).

Sta. 78/327. Venezuela: Dto. Falcón, well (c. $11^{\circ} 55^{\prime} 36^{\prime \prime} \mathrm{N}$, c. $70^{\circ} 13^{\prime} 46^{\prime \prime} \mathrm{W}$ ); partly covered, diam. 2.5 $\mathrm{m}$, windpump; chlorinity $4800 \mathrm{mg} / \mathrm{l} ; 26$ May 1978. One specimen (ZMA).

Sta. 78/353. Barbados: Parish of Christ Church, near Round Rock $\left(13^{\circ} 02^{\prime} 50^{\prime \prime} \mathrm{N} 59^{\circ} 31^{\prime} 03^{\prime \prime} \mathrm{W}\right)$; open well, diam. $1.2 \mathrm{~m}$, in a field; chlorinity $800 \mathrm{mg} / \mathrm{l} ; 6$ June 1978. One specimen (PAS).

Dorsal setae begin in segment V. One hair 105$165 \mu \mathrm{m}$ long and one needle seta $42-52 \mu \mathrm{m}$ long with distal tooth shorter than proximal one. In ventral anterior bundles 3-4 setae 60-72 $\mu \mathrm{m}$ long, with distal teeth longer. Posterior setae 52-60 $\mu \mathrm{m}$ long, with distal teeth shorter. Four pairs of gills present.

The setae of specimens from four islands are measured. Those islands were chosen on which more than 20 specimens were caught. On the basis of the measurements of the setae one can say that Aulophorus furcatus is a homogeneous species on the islands investigated. Various populations have setae of almost the same length (except for hair setae in the specimens from Virgin Gorda) (table II). In all populations investigated the length of hair setae increases to segment XII and decreases posteriorly.

Distribution: Cosmopolitan species, common in South America (Di Persia, 1980).

TABle II

Length of setae $(\mu \mathrm{m})$ in different populations of Dero (Aulophorus) furcata (Müller, 1773).

\begin{tabular}{|c|c|c|c|c|c|c|c|}
\hline \multirow[t]{2}{*}{ Island } & \multicolumn{4}{|c|}{ hair setae of segment } & \multirow{2}{*}{$\begin{array}{c}\text { needle } \\
\text { setae }\end{array}$} & \multirow{2}{*}{$\begin{array}{c}\text { ventral } \\
\text { anterior } \\
\text { setae }\end{array}$} & \multirow{2}{*}{$\begin{array}{c}\text { ventral } \\
\text { posterior } \\
\text { setae }\end{array}$} \\
\hline & VIII & $\mathbf{x}$ & XII & XV & & & \\
\hline Anguilla & $120-127$ & $125-132$ & $125-150$ & $115-135$ & $45-49$ & $60-70$ & $52-60$ \\
\hline Virgin Gorda & $129-138$ & $135-150$ & $156-165$ & $135-142$ & $45-49$ & $60-72$ & $54-60$ \\
\hline Tortola & 113-132 & $120-130$ & $127-145$ & $120-135$ & $42-52$ & $61-70$ & $52-60$ \\
\hline Haiti & $120-125$ & $125-127$ & $128-130$ & $113-120$ & $42-47$ & $63-72$ & $52-60$ \\
\hline
\end{tabular}


Stephensoniana trivandrana (Aiyer, 1926) (Fig. 6)

Material. - Amsterdam Expeditions to the West Indian Islands, sta. 78/243. Haiti: Dept. de l'Ouest, Source du Trou Caiman, just S. of road $\left(18^{\circ} 39^{\prime} 22^{\prime \prime} \mathrm{N}\right.$ $\left.72^{\circ} 08^{\prime} 23^{\prime \prime} \mathrm{W}\right)$; source with gravel, leaves and roots, moderately fast running; chlorinity $320 \mathrm{mg} / \mathrm{l}$; 10 May 1978. Four specimens (ZMA).

Body wall with small gland cells and covered by thin sheath incrusted with foreign matter (small sand grains). Dorsal setae from segment II: 3-4 smooth, bayonet-shaped hairs 135-145 $\mu \mathrm{m}$ long and 2-3 (rarely 4 ) needles 29-34 $\mu \mathrm{m}$ long (fig. $6 a)$. Distal third of needle setae distinctly thinner than proximal part. Anterior ventral setae 3-4 in each bundle, in posterior segments the number of setae diminishes to one. Length of setae the same along whole body: $72-78 \mu \mathrm{m}$. In anterior ventral setae, distal teeth twice as long as proximal teeth (fig. 6b), in posterior part of body distal teeth three times longer than proximal ones (fig. 6c).

A characteristic feature of this species is the increasing difference in length of the teeth of the posterior ventral setae; in other taxa this dif-

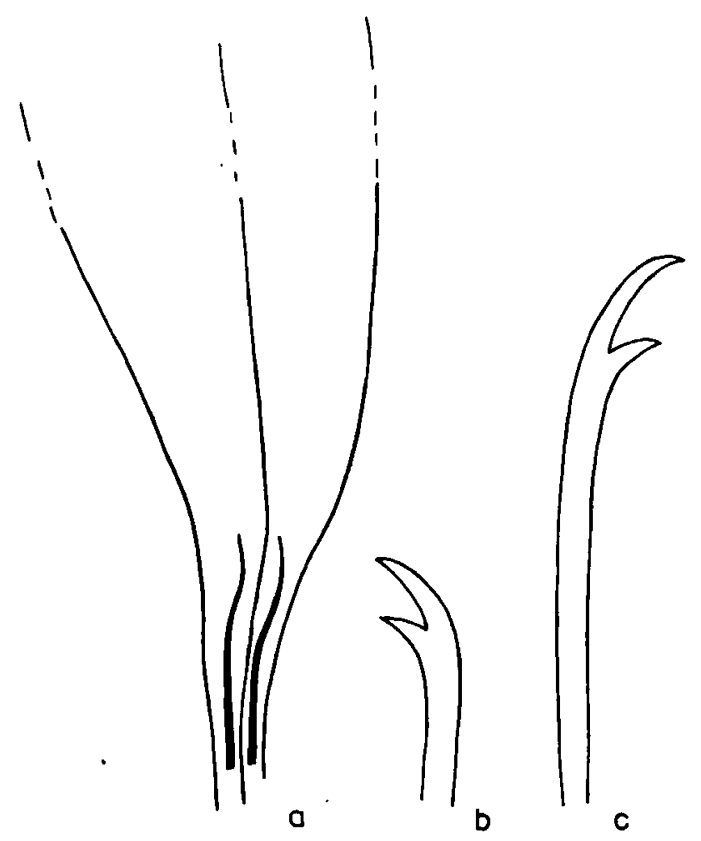

Fig. 6. Stephensoniana trivandrana (Aiyer, 1926): a, bundle of dorsal setae; $b$, anterior ventral seta; $c$, posterior ventral seta. ference usually decreases. Both Naidu (1963) and Brinkhurst \& Jamieson (1971) describe this feature in the text, but their drawings suggest that the teeth are equal.

Distribution: Known from India, South Africa and South America (Surinam and Argentina) (Di Persia, 1980).

Genus Pristina Ehrenberg, 1828

The genus Pristina comprises more than 25 species. However, the number of species is not definitely established due to a complex synonymy (Brinkhurst \& Jamieson, 1971; Naidu, 1962).

The species are distinguished mainly on the basis of external features. The features used for this purpose are: the presence or absence of a proboscis, position of the stomach, as well as the shape and arrangement of setae (Harman, 1980). These features show large variability but at the same time some species are very similar. These facts indicate that this genus needs revision.

Similar species belonging to two different groups were found in the material investigated: (1) Pristina idrensis Sperber, 1948, P. jenkinae (Stephenson, 1931), and $P$. longidentata Harman, 1965, and (2) P. foreli (Piguet, 1906), $P$. aequiseta Bourne, 1891, and $P$. evelinae Marcus, 1943 , but only additional investigation (genetic or electrophoretic) will make it possible to classify them more precisely.

\section{Pristina ?idrensis Sperber, 1948}

(Fig. 7)

Material.- Amsterdam Expeditions to the West Indian Islands, sta. 78/65. St. Martin, French side: Ravine de Loterie, 1 st road left $\left(18^{\circ} 04^{\prime} 53^{\prime \prime} \mathrm{N}\right.$ $63^{\circ} 04^{\prime} 10^{\prime \prime} \mathrm{W}$ ); clean well, closed, handpump; chlorinity $1080 \mathrm{mg} / \mathrm{l} ; 17$ April 1978. Three specimens (ZMA).

Hair setae 1-2 per bundle, non-serrate, short (114-130 $\mu \mathrm{m})$. Needles 1-2 per bundle, with distal teeth shorter and thinner than proximal ones (fig. 7a). Needles 23-26 $\mu \mathrm{m}$ long and up to $1 \mu \mathrm{m}$ wide, in segments IV and V longer (33-40 $\mu \mathrm{m})$ and thicker $(1.4-1.5 \mu \mathrm{m})$ but of same shape (fig. 7b). Ventral setae similar in all segments: 


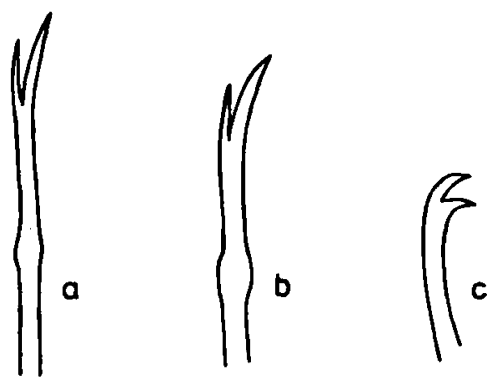

Fig. 7. Pristina ?idrensis Sperber, 1948: a, needle seta; b, needle seta of segment IV; c, ventral seta.

28-31 $\mu \mathrm{m}$ long, with teeth of equal length (fig. 7c).

The specimens discussed above belong to a group of species characterized by: lack of proboscis, non-serrate hair setae, needle setae distinctly bifid with long, parallel teeth and ventral setae with teeth of equal length along the whole body. Only three valid species: Pristina idrensis Sperber, 1948, Pristina jenkinae (Stephenson, 1931) and $P$. napocensis Pop, 1973 (cf. Brinkhurst \& Jamieson, 1971; Pop, 1973) belong to this group, as well as some synonymized species, e.g. $P$. nothofagi Stout, 1958, $P$. taita Stout, 1958, and $P$. longidentata Harman, 1965 (cf. Stout, 1958; Harman, 1965) (table III). The last-mentioned species differs from all the above-mentioned ones by having serrate hair setae and therefore it should be excluded from this species complex.

The differences between the remaining species are very slight. Moreover, when the features of this group of species are tabulated, one can note a continuity in the variation of some distinguishing features such as the presence of enlarged setae, the length and ratio between the distal and proximal teeth of needle setae, and the position of the stomach. Specimens from St. Martin are similar both to Pristina idrensis and $P$. jenkinae; moreover, they are found within the distribution area of $P$. jenkinae. It appears that these species have to be synonymized, especially since Loden \& Harman (1980) stated that the development of giant setae (which is one of the features distinguishing these species) depends on environmental conditions.

TABLE III

Distinguishing features of Pristina idrensis Sperber, 1948 and related species.

\begin{tabular}{|c|c|c|c|c|c|}
\hline Species & $\begin{array}{l}\text { enlarged } \\
\text { needle } \\
\text { setae }\end{array}$ & $\begin{array}{l}\text { length of teeth of } \\
\text { needle setae }(\mu \mathrm{m}) \text {; } \\
\text { ratio proximal/distal }\end{array}$ & stomach dilatation & $\begin{array}{l}\text { teeth of ventral } \\
\text { setae }\end{array}$ & $\begin{array}{l}\text { serration on } \\
\text { hair setae }\end{array}$ \\
\hline $\begin{array}{l}P . \text { idrensis } \\
\text { Sperber, } 1948\end{array}$ & IV (V) & $3.7-4.5 / 3.0-3.7$ & $\begin{array}{l}\text { gradual, } 1 / 2 \mathrm{VI} \\
\text { to } 1 / 2 \mathrm{VII}\end{array}$ & equally long & absent \\
\hline $\begin{array}{l}P \text {. ?idrensis } \\
\text { Sperber, } 1948 \\
\text { from S. America }\end{array}$ & IV, V & $5.3-7.0 / 3.2-5.1$ & sudden, VII & equally long & absent \\
\hline $\begin{array}{l}\text { P. taita } \\
\text { Stout, } 1958\end{array}$ & VIII, IX & $7-8 / 4-5$ & sudden, VI & equally long & absent \\
\hline $\begin{array}{l}P \text {. nothofagi } \\
\text { Stout, } 1958\end{array}$ & - & 6 (nearly equal) & sudden, VII & equally long & absent \\
\hline $\begin{array}{l}\text { P. jenkinae } \\
\text { (Steph. 1931) }\end{array}$ & - & 5-9 (distal shorter) & VII & equally long & absent \\
\hline $\begin{array}{l}P \text {. napocensis } \\
\text { Pop, } 1973\end{array}$ & - & $\begin{array}{l}8.4-8.8 \text { (distal } \\
\text { longer) }\end{array}$ & VIII & equally long & absent \\
\hline $\begin{array}{l}\text { P. longidentata } \\
\text { Harman, } 1965\end{array}$ & - & 10 (nearly equal) & sudden, VIII & distal longer & present \\
\hline $\begin{array}{l}P \text {. amphibiotica } \\
\text { Lastockin, } 1927\end{array}$ & IV, (V) & $1.8-2.8 / 1.0-1.5$ & gradual, VI & distal shorter & absent \\
\hline
\end{tabular}


Pristina ?longidentata Harman, 1965 (Fig. 8)

Material. - Amsterdam Expeditions to the West Indian Islands, sta. 78/209. Haiti: Dépt. de l'Ouest, new road Léogâne-Jacmel, just $\mathbf{N}$. of boundary with dépt. du Sud-Est (c. $18^{\circ} 21^{\prime} 59^{\prime \prime} \mathrm{N}$, c. $72^{\circ} 35^{\prime} 45^{\prime \prime} \mathrm{W}$ ); clear spring, bottom muddy; chlorinity $40 \mathrm{mg} / \mathrm{l} ; 5$ May 1978. Three specimens (PAS).

Sta. 78/217. Haiti: Dépt. du Centre, N. slope of Mont Blanc, source no. 6 (c. $18^{\circ} 43^{\prime} 42^{\prime \prime} \mathrm{N}$, c. $72^{\circ} 07^{\prime} 15^{\prime \prime} \mathrm{W}$ ); clean karst source, fast running, gravel, loam; alt. 300-460 $\mathrm{m}$; chlorinity $30 \mathrm{mg} / \mathrm{l}$; 6 May 1978 . Seven specimens (ZMA).

Sta. 78/224. Haiti: Dépt. de l'Ouest, Étang Saumâtre, E.S.E. of Fond Parisien ( $18^{\circ} 29^{\prime} 19^{\prime \prime} \mathrm{N} 71^{\circ} 56^{\prime} 25^{\prime \prime} \mathrm{W}$ ); two karst sources; moderately fast running, 6 and $4 \mathrm{~m}$ from shore of lake, stones, sand, roots; chlorinity $130 \mathrm{mg} / 1 ; 7$ May 1978. One specimen (ZMA).

Prostomium rounded. Hair setae serrate, 1-2 per bundle, 215-290 $\mu \mathrm{m}$ long. Needle setae stout, with long teeth, distal ones shorter than proximal ones (fig. 8a). Needle setae of anterior segments $(40-64 \mu \mathrm{m})$ shorter than of posterior ones $(72-90 \mu \mathrm{m})$. Ventral setae with teeth of equal length, distal teeth thinner but not shorter (figs. 8b, c). Number of setae 4-6 in anterior segments, 3-4 in posterior ones. Length of ventral setae varies from 47 to $82 \mu \mathrm{m}$. The specimens from sta. 78/209 are larger than those from other stations. Ventral setae of the specimens from Haiti 78/209 measure 70-82 $\mu \mathrm{m}$, anterior needle setae $52-64 \mu \mathrm{m}$, posterior needle setae 79-90 $\mu \mathrm{m}$, whereas the specimens from Haiti 78/217 have ventral setae 47-67 $\mu \mathrm{m}$ long, anterior needle setae 40-47 $\mu \mathrm{m}$ long and posterior needle setae $72-80 \mu \mathrm{m}$ long. Stomach dilatation sudden, in the beginning of segment VIII (fig. 8d).

Distribution: The species has been described from a lake in Louisiana (U.S.A.) (Harman, 1965).

Brinkhurst treated this species as a synonym of Pristina idrensis Sperber, 1948, but it differs in having serrated hair setae (short serration, distinct when using the normal light microscope at a magnification of $1000 \times$ ) and in the position of the stomach.
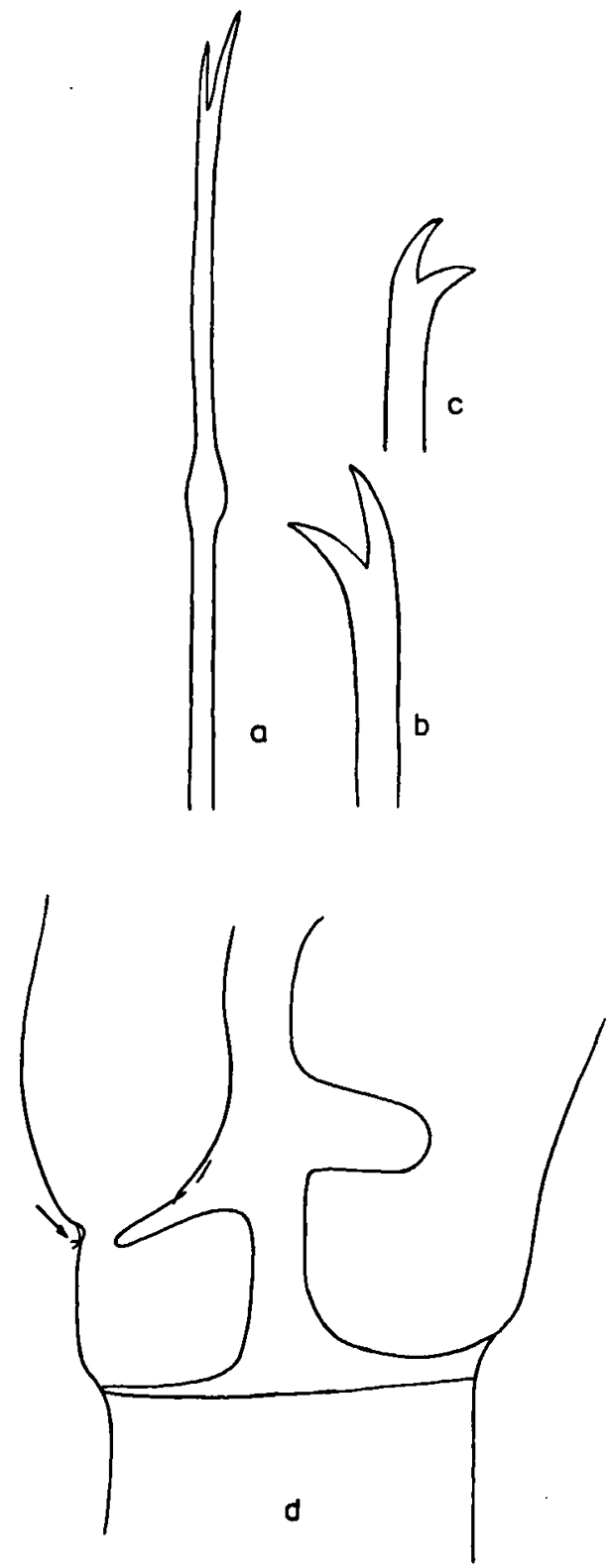

Fig. 8. Pristina ?longidentata Harman, 1965: a, needle seta; b, anterior ventral seta; c, posterior ventral seta; d, stomach dilatation.

Pristina peruviana Černosvitov, 1939 (Fig. 9)

Material. - Amsterdam Expeditions to the West Indian Islands, sta. 78/103. Anegada: Tom Berry Well $\left(18^{\circ} 43^{\prime} 38^{\prime \prime} \mathrm{N} 64^{\circ} 18^{\prime} 57^{\prime \prime} \mathrm{W}\right)$; chlorinity $560 \mathrm{mg} / \mathrm{l} ; 22$ April 1978. One specimen (PAS).

Sta. 78/174. Vieques: Monte Santo, well in small valley $\left(18^{\circ} 07^{\prime} 51^{\prime \prime} \mathrm{N} 65^{\circ} 27^{\prime} 18^{\prime \prime} \mathrm{W}\right)$; in hut; 1 May 1978. Twenty-three specimens (ZMA). 
Sta. 78/223. Haiti: Dépt. du Centre, W. of Mirebalais, just W. of crossroad to Saut-d'Eau (on road $N$ 109) $\left(18^{\circ} 51^{\prime} 36^{\prime \prime} \mathrm{N} 72^{\circ} 10^{\prime} 40^{\prime \prime} \mathrm{W}\right)$, spring in bank of small stream, moderately fast running, clean, in roots + loam; 6 May 1978. One specimen (ZMA).

Sta. 78/226. Haiti: Dépt. de l'Ouest, interstitia of coarse sand on shore $\left(18^{\circ} 29^{\prime} 19^{\prime \prime} \mathrm{N} 71^{\circ} 56^{\prime} 25^{\prime \prime} \mathrm{W}\right)$; brackish lake, just above waterline, near fresh pool; chlorinity $110 \mathrm{mg} / \mathrm{l} ; 7$ May 1978. One specimen (PAS).

Prostomium with a short proboscis. Usually 2 hair setae per bundle, sometimes 1 or 3 . Hairs with long serration, $390-440 \mu \mathrm{m}$ long. Needles 71-80 $\mu \mathrm{m}$ long, 1-2 per bundle, bifid, with long, parallel teeth (fig. 9a). Teeth of almost the same length e.g.: distal $8 \mu \mathrm{m}$, proximal $9 \mu \mathrm{m}$; or distal $10.4 \mu \mathrm{m}$, proximal $11.2 \mu \mathrm{m}$. Anterior ventral setae 68-74 $\mu \mathrm{m}$ long with distal teeth slightly longer than proximal ones (fig. 9b). Posterior ventral setae 70-78 $\mu \mathrm{m}$ long with equal teeth (fig. 9c). Stomach dilatation sudden, in the beginning of segment VIII.
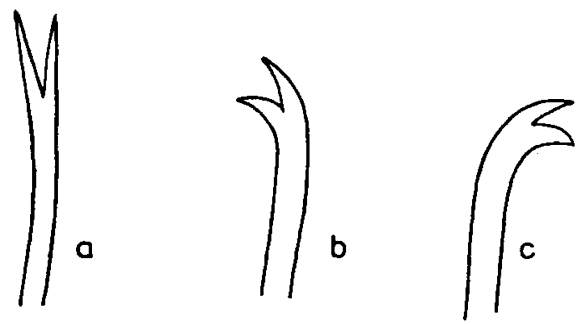

Fig. 9. Pristina peruviana Černosvitov, 1939: a, needle seta; b, anterior ventral seta; $c$, posterior ventral seta.

Distribution: So far, this species was known only from South America: Peru - Lake Titicaca (Černosvitov, 1939), and some localities in the Amazon system (Du Bois-Reymond Marcus, 1947). This species is easily distinguished from the other ones by its size, presence of proboscis, and long serrations on hair setae. It resembles only $P$. americana Cernosvitov, 1937, but differs from it in some features. In the specimens collected from the West Indian islands, the posterior ventral setae have teeth of equal length, but the distal ones are never shorter, as is typical of $P$. americana. Moreover, the stomach dilatation of $P$. americana is in segment VII, whereas that of $P$. peruviana is in segment VIII.
Pristina foreli (Piguet, 1906)

(Fig. 10)

Material. - Amsterdam Expeditions to the West Indian Islands, sta. 74/9. St. Martin, French side: slope of Mont Vernon, left side of road Orléans-Grand' Case $\left(18^{\circ} 05^{\prime} 07^{\prime \prime} \mathrm{N} 63^{\circ} 01^{\prime} 46^{\prime \prime} \mathrm{W}\right)$; well, fuel pump, in dry bed of rain gully; chlorinity $780 \mathrm{mg} / \mathrm{l} ; 1$ February 1974. Twenty-seven specimens (ZMA).

Sta. 78/42. Antigua: Parish of St. Paul, English Harbour Town, S. of road $\left(17^{\circ} 00^{\prime} 55^{\prime \prime} \mathrm{N} 61^{\circ} 45^{\prime} 43^{\prime \prime} \mathrm{W}\right)$; round well, diam. c. $3 \mathrm{~m}$, small opening; in small valley; chlorinity $720 \mathrm{mg} / \mathrm{l} ; 13$ April 1978. One specimen (ZMA).

Sta. 78/51. St. Martin, French side: E. slope of Mont Vernon (Hope Hill) $\left(18^{\circ} 05^{\prime} 30^{\prime \prime} \mathrm{N} 63^{\circ} 01^{\prime} 51^{\prime \prime} \mathrm{W}\right)$; round well, largely covered, clean; chlorinity $1720 \mathrm{mg} / \mathrm{l} ; 16$ April 1978. One specimen (ZMA).

Sta. 78/57. St. Martin, French side: N. of Grand' Case, foot of First Stick Hill, W. slope $\left(18^{\circ} 06^{\prime} 44^{\prime \prime} \mathrm{N}\right.$ $63^{\circ} 03^{\prime} 18^{\prime \prime} \mathrm{W}$ ); clean well, wood debris; chlorinity 1360 $\mathrm{mg} / \mathrm{l} ; 16$ April 1978. Four specimens (PAS).

Sta. 78/65. St. Martin, French side: Ravine de Loterie, 1 st road left $\left(18^{\circ} 04^{\prime} 53^{\prime \prime} \mathrm{N} 63^{\circ} 04^{\prime} 10^{\prime \prime} \mathrm{W}\right)$; closed well, handpump, clean; chlorinity $1080 \mathrm{mg} / \mathrm{l} ; 17$ April 1978. One specimen (ZMA).

Sta. 78/82. St. Barths: Quartier du Corossol $\left(17^{\circ} 54^{\prime} 45^{\prime \prime} \mathrm{N} 62^{\circ} 51^{\prime} 29^{\prime \prime} \mathrm{W}\right)$; round well, diam. c. $2 \mathrm{~m}$, closed; chlorinity $880 \mathrm{mg} / \mathrm{l} ; 18$ April 1978. Thirty-one specimens (ZMA).

Sta. 78/120. Virgin Gorda: Spanish Town, Crossroad Well $\left(18^{\circ} 26^{\prime} 42^{\prime \prime} \mathrm{N} 64^{\circ} 26^{\prime} 23^{\prime \prime} \mathrm{W}\right)$; closed, used by tank cars; chlorinity $440 \mathrm{mg} / \mathrm{l} ; 24$ April 1978. One specimen (ZMA).

Sta. 78/142. Tortola: Road Town, well Water Works (c. $100 \mathrm{~m}$ of Police HQ) $\left(18^{\circ} 25^{\prime} 45^{\prime \prime} \mathrm{N} 64^{\circ} 37^{\prime} 23^{\prime \prime} \mathrm{W}\right)$; closed, large, electric pump; chlorinity $400 \mathrm{mg} / \mathrm{l} ; 25$ April 1978. Sixty-one specimens (ZMA).

Sta. 78/144. Tortola: Duffs Bottom Pond, N. side of road $\left(18^{\circ} 24^{\prime} 42^{\prime \prime} \mathrm{N} \quad 64^{\circ} 37^{\prime} 28^{\prime \prime} \mathrm{W}\right)$; well, troughs; chlorinity $720 \mathrm{mg} / \mathrm{l}$; 26 April 1978 . One specimen (ZMA).

Sta. 78/146. Tortola: Hannah Bay $\left(18^{\circ} 24^{\prime} 10^{\prime \prime} \mathrm{N}\right.$ $\left.64^{\circ} 38^{\prime} 10^{\prime \prime} \mathrm{W}\right)$; well, filamentous algae, chlorinity 1720 mg/l; 26 April 1978. Three specimens (PAS).

Prostomium with proboscis. Hair setae usually 1 per bundle, sometimes 2, finely serrate, increasing in length to VIIIth, XIIth or even $\mathrm{XVth}$ segment (table IV). Needle setae 1 or rarely 2 per bundle, $34-48 \mu \mathrm{m}$ long, with very short teeth (fig. 10a). Specimens from sta. 74/9 (St. Martin) have usually two hair and two needle setae per bundle. Ventral setae of segment II a little longer than those of other segments. Ventral setae of anterior segments with distal teeth slightly longer than proximal ones (fig. 


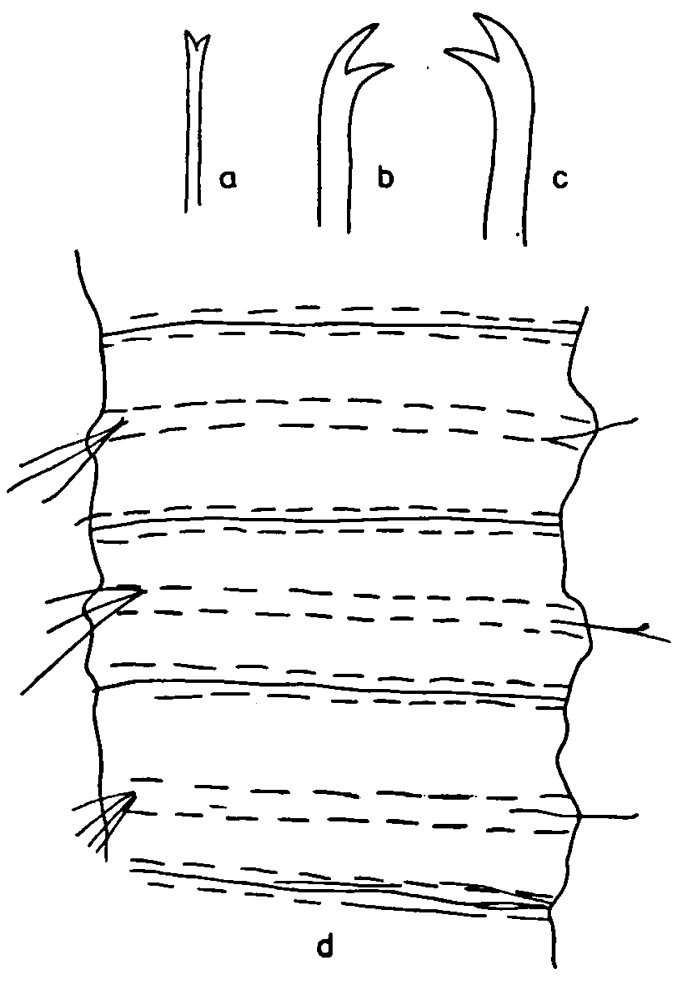

Fig. 10. Pristina foreli (Piguet, 1906): a, needle seta; b, anterior ventral seta; $c$, posterior ventral seta; $d$, segments IV-VI: rows of papillae in the intersegmental furrows and in the lines with setae in specimens from sta. 74/9 (St. Martin).

$10 \mathrm{~b}$ ), in posterior segments teeth of equal length (fig. 10c), in terminal segments distal teeth slightly shorter. Ventral setae 3-6 per bundle, 32-49 $\mu \mathrm{m}$ long. Among the populations examined different trends are observed in the length of the ventral setae: length does not change along whole body ( 2 populations); anterior ventral setae longer than posterior (1 population); posterior ventral setae longer (1 population). Stomach dilatation sudden, in segment VIII. One population (sta. 74/9, St. Martin) has papillae in two rows per segment (fig. 10d).

The populations investigated differ a little from each other in the length of the setae, position of the longest hair setae and the variable length of the ventral setae along the body. Isolation of the populations and frequent asexual reproduction facilitate the maintenance of such inter-populational differences.

Pristina foreli is considered a Palearctic species (Brinkhurst \& Jamieson, 1971; Kasprzak, 1981), but Loden \& Harman (1980) suggest that $P$. foreli, $P$. aequiseta Bourne, 1891, and $P$. evelinae Marcus, 1943 belong to a single cosmopolitan species which varies in form depending on ionic concentration. When the conductivity increases the setae start to modify into giant setae, but in the material from West Indian islands specimens without modified setae occur also in the waters of high salinity. Perhaps salinity is not the only factor influencing the formation of giant setae.

Pristina aequiseta Bourne, 1891

(Fig. 11)

Material. - Amsterdam Expeditions to the West Indian Islands, sta. 78/194. Puerto Rico: Ojo de Agua, N.W. of Vega Baja $\left(18^{\circ} 27^{\prime} \mathrm{N} 66^{\circ} 24^{\prime} \mathrm{W}\right)$; karst source, fairly fast running, clean; chlorinity $1640 \mathrm{mg} / \mathrm{l} ; 3$ May 1978. Two specimens (ZMA).

Sta. 78/210. Haiti: Dépt. du Sud-Est, Jacmel, W. part of village $\left(18^{\circ} 14^{\prime} 07^{\prime \prime} \mathrm{N} 72^{\circ} 32^{\prime} 29^{\prime \prime} \mathrm{W}\right)$; round well, near house, diam. $0.8 \mathrm{~m}$, in soil, chlorinity $120 \mathrm{mg} / 1 ; 5 \mathrm{May}$ 1978. Six specimens (ZMA).

Sta. 78/238. Haiti: Dépt. du Nord, Limbé, N. side road D $100\left(19^{\circ} 42^{\prime} 29^{\prime \prime} \mathrm{N} 72^{\circ} 23^{\prime} 53^{\prime \prime} \mathrm{W}\right)$; round well, closed,

TABLE IV

Length of setae $(\mu \mathrm{m})$ in different populations of Pristina foreli (Piguet, 1906).

\begin{tabular}{|c|c|c|c|c|c|c|c|c|c|}
\hline \multirow[t]{2}{*}{ Locality } & \multicolumn{5}{|c|}{ hair setae of segment } & \multirow{2}{*}{$\begin{array}{c}\text { needle } \\
\text { setae }\end{array}$} & \multicolumn{3}{|c|}{ ventral setae of segment } \\
\hline & III & VI & VIII & XII & XV & & II & anterior & posterior \\
\hline St. Martin $78 / 57$ & $124-153$ & $220-232$ & 283-305 & $254-280$ & $250-294$ & $42-48$ & 42 & $38-41$ & $32-34$ \\
\hline Tortola $78 / 142$ & $113-198$ & $226-255$ & $280-310$ & $293-310$ & $311-340$ & $40-43$ & 44 & $37-42$ & $37-39$ \\
\hline St. Martin 74/9 & $105-120$ & $210-240$ & $240-285$ & $240-255$ & $210-230$ & $34-42$ & $52-54$ & $38-46$ & $43-46$ \\
\hline St. Barths 78/82 & $120-150$ & $195-325$ & $330-360$ & $345-390$ & $342-355$ & $35-45$ & $45-52$ & $40-48$ & $36-49$ \\
\hline
\end{tabular}


diam. $1 \mathrm{~m}$, filamentous algae; chlorinity $240 \mathrm{mg} / \mathrm{l} ; 10$ May 1978. One specimen (ZMA).

Sta. 78/241. Haiti: Dépt. du Nord, village of CampCoq (= S. of Limbé), E. side of road D $100\left(19^{\circ} 40^{\prime} 03^{\prime \prime N}\right.$ $\left.72^{\circ} 25^{\prime} 06^{\prime \prime} \mathrm{W}\right)$; well of school, square, closed, windpump broken; chlorinity $200 \mathrm{mg} / \mathrm{l} ; 10$ May 1978. Four specimens (PAS).

Prostomium with proboscis. Hair setae finely serrate, increasing in length from segment II $(130 \mu \mathrm{m})$ to segment $\mathrm{X}(195 \mu \mathrm{m})$. Needles bifid with short teeth. Ventral setae of segment II longer than those of other segments (table V), with distal teeth twice as long as proximal ones. In anterior segments ventral setae with distal teeth longer than proximal ones. Giant setae, about twice as long as normal ones, present in segment $\mathrm{V}$ only, with distal teeth of enormous length and proximal teeth reduced (fig. 11). In posterior segments setae with teeth of equal length. Stomach dilatation sudden, in front of segment VIII.

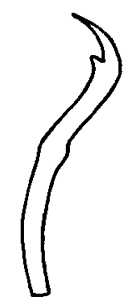

Fig. 11. Pristina aequiseta Bourne, 1891: giant seta.

Distribution: Pristina aequiseta was previously recorded from Bonaire and Curaçao only (Michaelsen, 1933), while $P$. evelinae Marcus, 1943-very closely related to $P$. aequiseta-was found in many places in South America (Marcus, 1943; Du Bois-Reymond Marcus, 1949; Di Persia, 1980). The only features distinguishing these species are: the shape of the distal end of the giant setae, and the absence of genital setae in $P$. aequiseta. Moreover, the giant setae of $P$. evelinae Marcus, 1943 are longer, but these features are insufficient to distinguish the species. The sizes of setae show gradual variations in different environments (Sperber, 1948, 1950; Ercolini, 1970; Di Persia, 1973) (table V).

Pristina leidyi Smith, 1896 sensu Harman \& McMahan, 1975

(Fig. 12)

Syn.: Pristina longiseta-bidentata Cernosvitov, 1942.

Material. - Amsterdam Expeditions to the West Indian Islands, sta. 78/239. Haiti: Dépt. du Nord, Limbé, S. side of road D $100\left(19^{\circ} 42^{\prime} 05^{\prime \prime} \mathrm{N} 72^{\circ} 23^{\prime} 53^{\prime \prime} \mathrm{W}\right)$; open well, round, diam. $1.5 \mathrm{~m}$; chlorinity $100 \mathrm{mg} / \mathrm{l} ; 10 \mathrm{May}$ 1978. One specimen (ZMA).

Sta. 78/240. Haiti: Dépt. du Nord, near 78/239 $\left(19^{\circ} 42^{\prime} 05^{\prime \prime} \mathrm{N} 72^{\circ} 23^{\prime} 53^{\prime \prime} \mathrm{W}\right)$; closed well, round, diam. 1 $\mathrm{m}$; chlorinity $240 \mathrm{mg} / \mathrm{l} ; 10$ May 1978 . One specimen (PAS).

Prostomium with proboscis. Hair setae 1-2 per bundle, serrate, 180-205 $\mu \mathrm{m}$ long. In segment III hair setae non-serrate and 410-450 $\mu \mathrm{m}$ long. Needle setae 30-42 $\mu \mathrm{m}$ long, bifid, with very thin and short teeth (fig. 12a). Ventral setae of segment II longer and thicker than setae of the following segments, with distal teeth more than twice as long as proximal ones (fig. 12b). In

TABLE V

Comparison of setal length $(\mu \mathrm{m})$ in Pristina aequiseta Bourne, 1891, P. evelinae Marcus, 1943 and P. foreli (Piguet, 1906).

\begin{tabular}{|c|c|c|c|c|c|c|c|}
\hline Species & ref. & $\begin{array}{l}\text { hair } \\
\text { setae }\end{array}$ & $\begin{array}{l}\text { needle } \\
\text { setae }\end{array}$ & $\begin{array}{l}\text { ventral setae } \\
\text { of segment II }\end{array}$ & $\begin{array}{c}\text { anterior } \\
\text { ventral setae }\end{array}$ & $\begin{array}{c}\text { posterior } \\
\text { ventral setae }\end{array}$ & $\begin{array}{l}\text { giant setae } \\
\text { of segment } V\end{array}$ \\
\hline$P$. aequiseta & Sperber, 1948 & $120-270$ & $30-69$ & $54-66$ & & $45-57$ & $45-57$ \\
\hline$P$. aequiseta & Ercolini, 1970 & $85-196$ & $31-42$ & $45-50$ & $39-47$ & $42-45$ & $43-51$ \\
\hline$P$. aequiseta & Sperber, 1950 & $120-270$ & $30-69$ & $54-60$ & $42-56$ & $45-56$ & $49-70$ \\
\hline$P$. aequiseta & present paper & $130-195$ & $33-42$ & $45-55$ & $35-42$ & $33-39$ & $60-70$ \\
\hline$P$. evelinae & $\begin{array}{l}\text { Di Persia, } \\
1973\end{array}$ & $90-170$ & $30-40$ & & \multicolumn{2}{|c|}{$38-52$} & $72.5-79$ \\
\hline$P$. evelinae & Sperber, 1950 & up to 150 & 40 & 55 & \multicolumn{2}{|c|}{$34-40$} & 80 \\
\hline P. foreli & present paper & $105-390$ & $34-48$ & $42-54$ & $37-48$ & $32-49$ & - \\
\hline P. foreli & Sperber, 1948 & $150-480$ & $38-63$ & $53-65$ & $44-57$ & $45-54$ & - \\
\hline
\end{tabular}




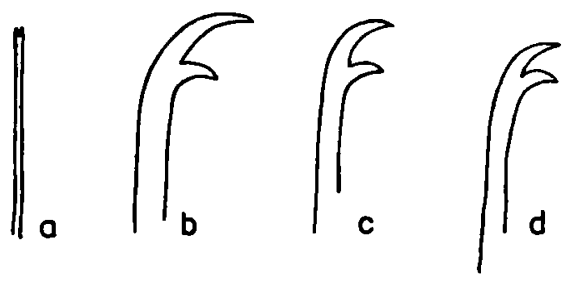

Fig. 12. Pristina leidyi Smith, 1896: a, needle seta; b, ventral seta of segment II; c, ventral seta of segment VII; d, posterior ventral seta.

next segments 3-5 per bundle, 49-56 $\mu \mathrm{m}$ long, with distal teeth less than twice longer than proximal ones (fig. 12c). Posterior ventral setae up to 7 per bundle, $49-53 \mu \mathrm{m}$ long with upper teeth slightly longer than lower ones (fig. 12d). Septal glands large in segments III-V.

Distribution: According to Harman \& McMahan (1975) and Di Persia (1980) this species has been found in many places in North America, Hawaii and South America.

\section{REFERENCES}

Bois-Reymond Marcus, E. DU, 1947. Naidids and tubificids from Brazil. Comun. zool. Mus. Hist. nat. Montev., 2 (44): 1-18, pls. I-III.

- 1 1949. Further notes on naidids and tubificids from Brazil. Comun. zool. Mus. Hist. nat. Montev., 3 (51): 1-11, pls. I-II.

Brinkhurst, R. O. * B. G. M. Jamieson, 1971. Aquatic Oligochaeta of the world: i-xiv, 1-860 (Oliver Boyd, Edinburgh).

Černosvitov, L., 1930. Oligochaeten aus Turkestan. Zool. Anz., 91 (1-4): 7-15.

- 1 1939. Oligochaeta. The Percy Sladen Trust Expedition to lake Titicaca in 1937. Trans. Linn. Soc. London, (3) 1 (1): 81-116.

Dumnicka, E., 1983. Amsterdam Expeditions to the West Indian Islands, Report 31. Tubificidae (Oligochaeta) from subterranean waters, with description of two new genera. Bijdr. Dierk., 53 (2): 255-261.

- 1 1986. Oligochaeta from subterranean waters of West Indian Islands. Comunicacions 9. Congreso Internacional de Espeleología, Barcelona 1986, 2: 95-98 (Comissió organitzadora del IX Congrés Internacional d'Espeleologia, Barcelona).

Ercolini, A., 1970. Notizie sistematiche sopra i Naididae della Somalia (Oligochaeta, Microdrili). Monitore zool. ital., (N.S.) Suppl. 3: 273-308.

Harman, W. J., 1965. A new species of the genus Pristina (Oligochaeta: Naididae) from Louisiana. Proc. Louis. Acad. Sci., 28: 28-31.
- , 1974. The Naididae (Oligochaeta) of Surinam. Zool. Verh. Leiden, 133: 1-36.

- , 1980. Specific and generic criteria in freshwater Oligochaeta, with special emphasis on Naididae. In: R. O. Brinkhurst \& D. G. Cook eds., Aquatic oligochaete biology: 1-8 (Plenum Publishing Corporation, New York).

Harman, W. J. M. L. McMahan, 1975. A reevaluation of Pristina longiseta (Oligochaeta: Naididae) in North America. Proc. biol. Soc. Wash., 88: 167-178.

Howmiller, R. P., 1974. Some Naididae and Tubificidae from central America. Hydrobiologia, 44: 1-12.

KasprzaK, K., 1981. Skaposzczety wodne, I. Rodziny: Aeolosomatidae, Potamodrilidae, Naididae, Tubificidae, Dorydrilidae, Lumbriculidae, Haplotaxidae, Glossoscolecidae, Branchiobdellidae. Klucze do oznaczania bezkręgowców Polski, 4: 1-226 (Państwowe Wydawnictwo Naukowe, Warszawa).

Loden, M. S. W. J. Harman, 1980. Ecophenotypic variation in setae of Naididae (Oligochaeta). In: $\mathbf{R}$. O. Brinkhurst D. G. Cook eds., Aquatic oligochaete biology: 33-39 (Plenum Publishing Corporation, New York).

Marcus, E., 1942. Sôbre algumas Tubificidae do Brasil. Bolm. Fac. Filos. Ciênc. Letr. Univ. S. Paulo, (Zool., 6) 25: 153-254, pls. I-XII.

- , 1943. Sôbre Naididae do Brasil. Bolm. Fac. Filos. Ciênc. Letr. Univ. S. Paulo, (Zool., 7) 32: 3-247, pls. I-XXXIII.

Michaelsen, W., 1933. Zoologische Ergebnisse einer Reise nach Bonaire, Curaçao und Aruba im Jahre 1930. 2. Süss- und Brackwasser-Oligochäten von Bonaire, Curaçao und Aruba. Zool. Jb., (Syst.) 64: 327-350, Taf. 1.

NaIDU, K. V., 1962. Studies on the freshwater Oligochaeta of South India. I. Aeolosomatidae and Naididae. Part 3. J. Bombay nat. Hist. Soc., 59 (2): 520-546.

,-- 1963 . Studies on the freshwater Oligochaeta of South India. I. Aeolosomatidae and Naididae. Part 5. J. Bombay nat. Hist. Soc., 60 (1): 201-227.

Persia, D. H. DI, 1973. Notas sobre oligoquetos dulceacuicolas Argentinos. Physis, Buenos Aires, (B) 32 (85): 279-285.

-, 1980 . The aquatic Oligochaeta of Argentina: current status of knowledge. In: R. O. BrinkHurst \& D. G. Cook eds., Aquatic oligochaete biology: 79-113 (Plenum Publishing Corporation, New York).

Pop, V., 1973. Deux espèces nouvelles de Pristina (Naididae, Oligochaeta) et leurs affinités. Studia Univ. Babeş-Bolyai, (Biol.) 18 (1): 79-89.

Semernoy, V. P. L. G. Belozub, 1979. [Oligochaeta from the rice fields of Uzbekistan.] Gidrobiol. Zh., 15 (2): 31-35. (In Russian with English summary; translated in: Hydrobiol. J., 15 (2) "1979" [1980]: 25-28.) 
Sperber, Ch., 1948. A taxonomical study of the Naididae. Zool. Bidr. Upps., 28: 1-296, pls. I-XXI. 1950. A guide for the determination of European Naididae. Zool. Bidr. Upps., 29: 45-78, pls. I-III.

Stephenson, J., 1931. Oligochaeta from the Malay Peninsula. J. fed. Malay St. Mus., 16: 261-285.
Stout, J. D., 1958. Aquatic oligochaetes occurring in forest litter, II. Trans. roy. Soc. N.Z., 85: 289-299.

TIмм, T., 1980. Distribution of aquatic oligochaetes. In: R. O. Brinkhurst \& D. G. Cook eds., Aquatic oligochaete biology: 79-113 (Plenum Publishing Corporation, New York).

First draft received: 13 December 1985

Revised draft received: 10 March 1986 